\title{
Difference in the influence of maternal and paternal NIDDM on pancreatic beta-cell activity and blood lipids in normoglycaemic non-diabetic adult offspring
}

\author{
T. Kasperska-Czyżyk ${ }^{1}$, K. Jedynasty ${ }^{1}$, R.R. Bowsher ${ }^{2}$, D. L. Holloway ${ }^{2}$, I. Stradowska ${ }^{1}$, K. Stepień ${ }^{1}$, R. Nowaczyk ${ }^{1}$, \\ W. Szymczak ${ }^{3}$, A. Czyżyk ${ }^{4}$ \\ ${ }^{1}$ Third Department of Internal Diseases, Central Clinical Hospital, Warsaw, Poland \\ ${ }^{2}$ Lilly Laboratory for Clinical Research, Eli Lilly and Company, and the Department of Biochemistry and Molecular Biology. \\ Indiana University School of Medicine, Indianapolis, Indiana, USA \\ ${ }^{3}$ Department of Epidemiology, Institute of Occupational Medicine, Lódź, Poland \\ ${ }^{4}$ Department of Gastroenterology and Metabolic Diseases, University Medical School, Warsaw, Poland
}

\begin{abstract}
Summary The $75-\mathrm{g}$ oral glucose tolerance test was performed in 38 normoglycaemic (World Health Organization criteria) non-diabetic volunteers, aged 31-40 years, of whom 20 had a non-insulin-dependent diabetic (NIDDM) mother and 18 had an NIDDM father. At the time of the study the offspring of NIDDM mothers had a somewhat higher body mass index (BMI) (males: $26.5 \pm 1.0($ mean \pm SEM), females: $\left.27.5 \pm 1.5 \mathrm{~kg} / \mathrm{m}^{2}\right)$ than the offspring of NIDDM fathers (males: 23.4 \pm 0.9 , females: $24.2 \pm 1.2 \mathrm{~kg} / \mathrm{m}^{2}$ ). There was no difference in the time-course of glycaemia; however the serum concentrations of immunoreactive insulin (IRI), C-peptide and proinsulin were significantly higher in offspring of NIDDM mothers than in offspring of NIDDM fathers: area under the curve (AUC) serum IRI: $0.928 \pm 0.091$ vs $0.757 \pm 0.056 \mathrm{nmol} \cdot \mathrm{l}^{-1} \cdot \mathrm{h}^{-1}$, $p=0.019 ; \quad$ serum C-peptide: $6.379 \pm 0.450$ vs $4.753 \pm 0.242 \mathrm{nmol} \cdot \mathrm{l}^{-1} \cdot \mathrm{h}^{-1}, p=0.004$; serum proinsulin: $172 \pm 40$ vs $\left.51 \pm 7 \mathrm{pmol} \cdot \mathrm{l}^{-1} \cdot \mathrm{h}^{-1}, p=0.008\right)$. Serum IRI correlated with BMI, but C-peptide and proinsulin did not, and after accounting for BMI by covariance analysis they remained significantly higher in offspring of NIDDM mothers. In this group serum
\end{abstract}

proinsulin was significantly higher in male than in female offspring (AUC serum proinsulin: $289 \pm 68$ vs $77 \pm 27 \mathrm{pmol} \cdot \mathrm{l}^{-1} \cdot \mathrm{h}^{-1}, P=0.015$ ). Male offspring of NIDDM mothers also had significantly higher serum triglyceride levels than females of the same group and than offspring of NIDDM fathers. The offspring (male and female) of NIDDM mothers had slightly lower serum apolipoprotein A-I levels than the offspring of NIDDM fathers. Significant correlations were found between serum triglycerides, HDL-cholesterol and apolipoprotein B, and serum concentrations of pancreatic beta-cell peptides, mostly in the offspring of NIDDM mothers; however, they did not display unequivocal association with gender within this group. The data are consistent with clinical observations of a greater risk of NIDDM transmission from the mother than from the father, and may suggest that male offspring are more exposed to this risk than female offspring. [Diabetologia (1996) 39: 831-837]

Keywords Maternal NIDDM, paternal NIDDM, Cpeptide, proinsulin, lipids.
Received: 2 June 1995 and in final revised form: 19 January 1996

Corresponding author: Dr. T. Kasperska-Czyżyk, Department III of Internal Diseases, Central Clinical Hospital, ul. Woloska 137, Warsaw 02-507, Poland

Abbreviations: NIDDM, Non-insulin-dependent diabetes mellitus; IDDM, insulin-dependent diabetes mellitus; IGT, impaired glucose tolerance; AUC, area under curve; IRI, immunoreactive insulin; HDL, high density lipoprotein; LDL, low density lipoprotein; WHR, waist-hip ratio; CV, coefficient of variation; RIA, radioimmunoassay; OGTT, oral glucose tolerance test.
Diabetes mellitus has long been recognized as a familial disease. However, only recently has evidence been accumulated that the gender of a diabetic parent may be an important factor in the transmission of the disease to the offspring. In the early $1980 \mathrm{~s}$ a group of investigators from the Joslin Diabetes Center presented results from several studies indicating that the risk of insulin-dependent diabetes (IDDM) is several times higher in offspring, if the father rather than the mother had IDDM [1]. Also, with regard to non-insulin-dependent diabetes (NIDDM), results 
Table 1. Clinical characteristics of non-diabetic offspring of one NIDDM parent

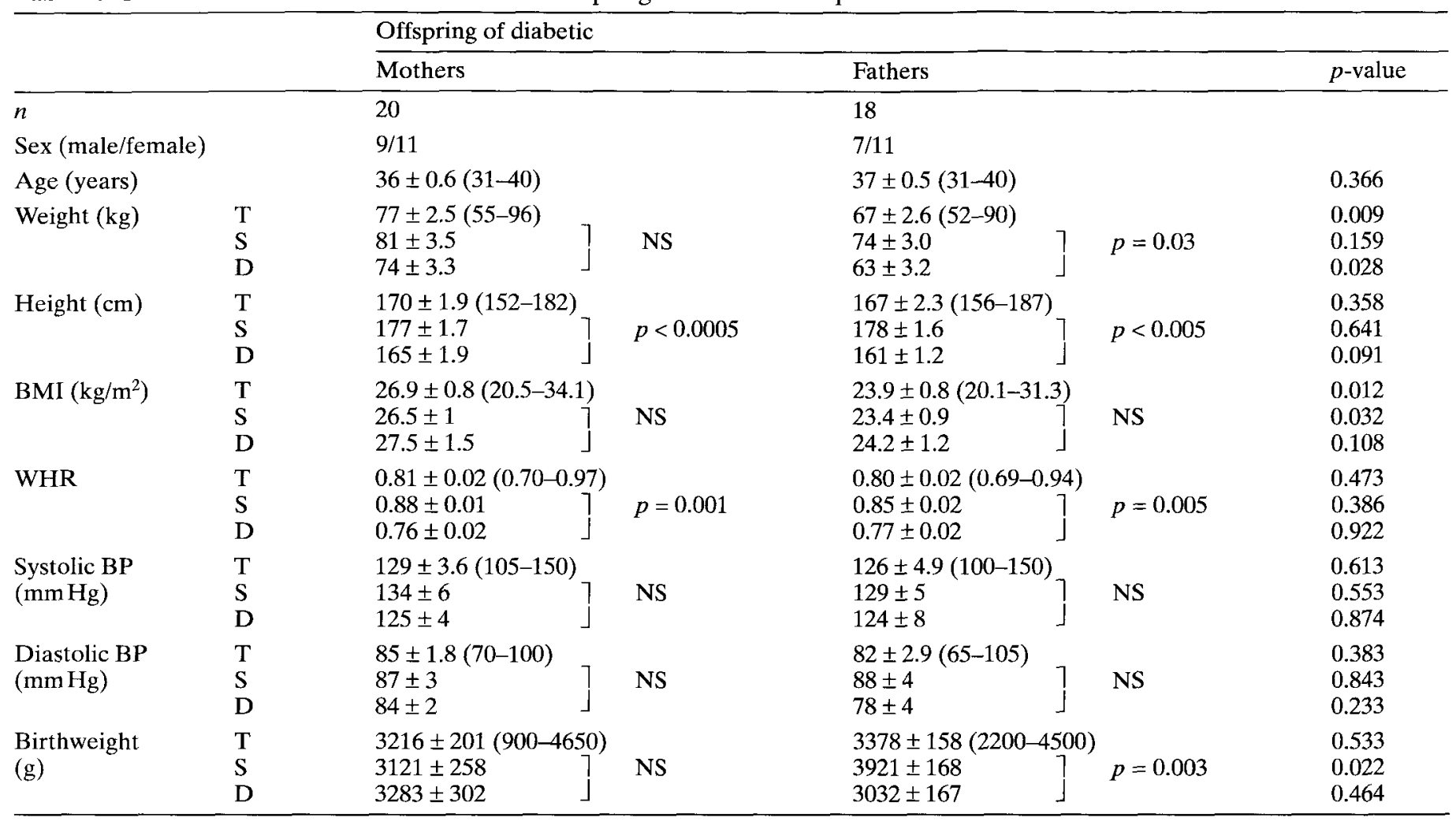

T, Total; S, sons; D, daughters, BP, blood pressure

Values are mean $\pm S E M$ with (range)

of several studies indicate that maternal rather than paternal factors may be more important in transmission of this disease. A higher prevalence of NIDDM was found in mothers than in fathers following retrospective analysis of patients' family histories [2-5]. Furthermore, women with gestational diabetes have been reported to more frequently have an NIDDM mother than father [6]. Studies on rats with streptozotocin-induced diabetes during pregnancy [7] and rats with spontaneous NIDDM [8] demonstrated a significant effect of maternal diabetes on the development of diabetes in their offspring.

Although NIDDM manifests itself in adult life, it is preceded by characteristic disorders which gradually increase in their intensity despite preservation of glucose tolerance [9]. A suitable model for the study of the natural history of NIDDM are the offspring of parents with the same type of (conjugal) diabetes. Several studies have shown that this group have moderate disorders typical of NIDDM, such as insulin resistance, hyperinsulinaemia, dyslipidaemia, and high body fat content, prior to the onset of glucose intolerance [10-15]. Recently, elevated circulating concentrations of proinsulin and its conversion products, mainly B-chain C-peptide junctional cleaved peptides, were detected in early NIDDM and in individuals with impaired glucose tolerance (IGT), including glucose-intolerant first-degree relatives of NIDDM patients [16-19]. The present study reports on the beta-cell secretory activity, including the proinsulin secretion, and on the blood lipid profile of adult normoglycaemic, non-diabetic probands who either had a mother or a father with NIDDM.

\section{Subjects and methods}

This study comprised 38 normoglycaemic (World Health Organization criteria) subjects, aged 31-40 years; of these 20 (9 men and 11 women) had a mother, and 18 ( 7 men and 11 women) had a father with NIDDM. They constituted the above-given age range in a cohort of randomly assigned non-diabetic children of either NIDDM mother or father treated in our institution. There were no siblings among these probands. Men and women of both groups had similar clinical parameters and only sons of NIDDM fathers had somewhat higher birthweights. However, at the time of this investigation the offspring of diabetic mothers had a greater BMI calculated both for the whole group and separately for males and females (Table 1 ). The very close waist-hip ratio (WHR) values showed a similar distribution of adipose tissue in men and women of both groups. All parents of probands were examined: in healthy parents diabetes and IGT were excluded on the basis of a 75-g oral glucose tolerance test (OGTT) [20], and the diabetic parents were followed-up in the diabetic out-patient clinic. For all NIDDM parents the disease had presented after the birth of the studied offspring. Relevant clinical data are presented in Table 2 . The mothers, who at the time of the study had NIDDM, were at the time of delivery somewhat older than mothers with normal glucose tolerance. The only significant non-gender-dependent differences between diabetic 
Table 2. Clinical charcteristics of NIDDM parents

\begin{tabular}{|c|c|c|c|}
\hline$n$ & $\begin{array}{l}\text { Diabetic mother } \\
\text { (20) }\end{array}$ & $\begin{array}{l}\text { Diabetic father } \\
\text { (18) }\end{array}$ & $p$-value \\
\hline $\begin{array}{l}\text { At delivery } \\
\text { Age of both parents (years) }\end{array}$ & & & \\
\hline $\begin{array}{l}\text { Mother } \\
\text { Father }\end{array}$ & $\begin{array}{l}26 \pm 1.2(19-39) \\
30 \pm 1.0(24-42)^{\mathrm{a}}\end{array}$ & $\begin{array}{l}23 \pm 0.7(19-30)^{\mathrm{a}} \\
27 \pm 0.8(22-34)\end{array}$ & $\begin{array}{l}0.027 \\
0.052\end{array}$ \\
\hline $\begin{array}{l}\text { At the NIDDM onset } \\
\text { Age (years) } \\
\text { BMI }\left(\mathrm{kg} / \mathrm{m}^{2}\right) \\
\text { WHR } \\
\text { Systolic BP }(\mathrm{mm} \mathrm{Hg}) \\
\text { Diastolic BP }(\mathrm{mm} \mathrm{Hg}) \\
\text { Serum cholesterol }(\mathrm{mmol} / \mathrm{l}) \\
\text { Serum triglycerides }(\mathrm{mmol} / \mathrm{l})\end{array}$ & $\begin{array}{l}53.4 \pm 1.4(39-65) \\
34.2 \pm 1.3(23-43.5) \\
0.87 \pm 0.01(0.80-0.93) \\
150 \pm 4.8(115-190) \\
92 \pm 2.8(75-120) \\
5.92 \pm 0.24(4.5-8.46) \\
2.31 \pm 0.37(0.52-4.03)\end{array}$ & $\begin{array}{l}57 \pm 1.8(43-65) \\
29.5 \pm 0.7(25.4-34.5) \\
0.94 \pm 0.01(0.86-0.98) \\
140 \pm 4.6(120-170) \\
83 \pm 2.2(70-100) \\
6.21 \pm 0.30(4.96-9.15) \\
2.07 \pm 0.25(1.03-3.39)\end{array}$ & $\begin{array}{l}0.123 \\
0.003 \\
<0.0005 \\
0.123 \\
0.023 \\
0.454 \\
0.593\end{array}$ \\
\hline $\begin{array}{l}\text { Family history of diabetes } \\
\text { Mother } \\
\text { Father } \\
\text { Diabetes duration (years) } \\
\text { Diabetes therapy } \\
\text { Diet only } \\
\text { Oral agents } \\
\text { Insulin }\end{array}$ & $\begin{array}{l}4 \\
- \\
9.3 \pm 1.3(2-22) \\
1 \\
15 \\
4\end{array}$ & $\begin{array}{l}- \\
- \\
6.5 \pm 1.0(1-15) \\
2 \\
12 \\
4\end{array}$ & 0.107 \\
\hline
\end{tabular}

${ }^{a}$ Healthy parent; ${ }^{b}$ due to secondary sulphonylurea failure. BP, Blood pressure

Values are mean \pm SEM (range)

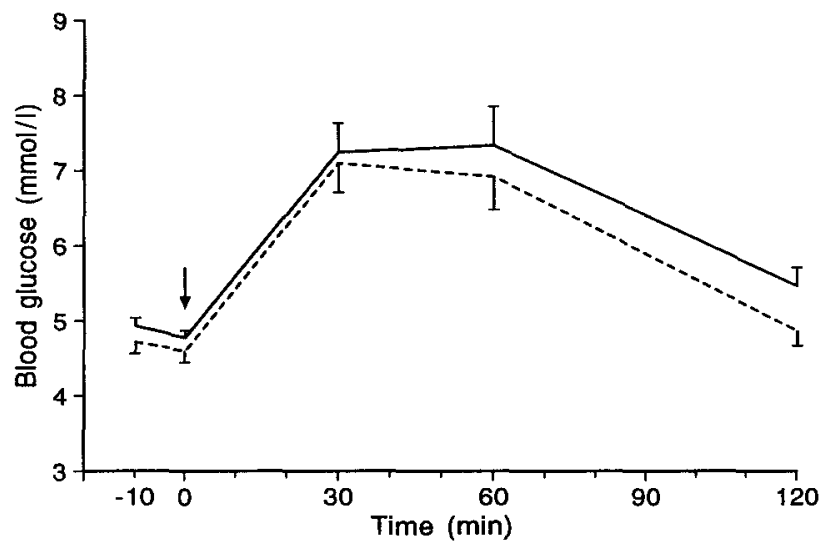

Fig. 1. Glycaemia curves after OGTT (arrow) in non-diabetic adult offspring of either NIDDM mother (-) or father (-..). Mean \pm SEM

mothers and diabetic fathers at disease onset were higher BMI and diastolic blood pressure in the mothers. Interestingly, only diabetic mothers had a positive family history of NIDDM. The study was approved by the ethical committee of the Central Clinical Hospital in Warsaw, and all subjects gave their informed consent according to the Helsinki Declaration.

During the OGTT samples of antecubital venous blood were drawn at $-10,0,30,60$ and $120 \mathrm{~min}$ after administration of glucose. Blood glucose was determined enzymatically using the glucose-oxidase-peroxidase method (Centriyfichem 606, Baker-Serono, Alentown, PA, USA). Serum samples were stored at $-20^{\circ} \mathrm{C}$ until radioimmunological analyses for insulin [double-antibody RIA; Institute of Nuclear Research, Swierk, Poland; average intra-assay coefficient of variation (CV) $8.5 \%$ ], and C-peptide (Byk-Sangtec Diagnostica kits, Ditzenbach, Germany; average intra-assay CV $6.5 \%$ ). Serum proinsulin concentrations were determined by a competitive nonequilibrium RIA method. The polyclonal antibody used in this assay (168AB) recognizes a proinsulin-specific epitope formed by the intact $\mathrm{A}$-chain $\mathrm{C}$-peptide junction. Under non-equilibrium assay conditions des $[31,32]$ proinsulin is $95 \%$ more potent than intact proinsulin. Thus, the proinsulin concentrations measured by this assay are the sum of intact and B-chain C-peptide junctional cleaved peptides and represent the total circulating proinsulin concentration. The detection limit for this RIA is $3.5 \mathrm{pmol} / 1$, and for $50 \mathrm{pmol} / 1$ the intra-assay $\mathrm{CV}$ is $6.5 \%$ with a $95 \%$ recovery, and for higher serum levels $(250 \mathrm{pmol} / \mathrm{l})$ it is $21 \%$ with a $108 \%$ recovery. Both insulin and C-peptide display negligible levels of cross-reactivity in the proinsulin RIA [21].

Serum triglyceride and total cholesterol levels were determined by enzymatic methods (Monarch 2000, Instrumentation Lab., Lexington, MA, USA), HDL-cholesterol was measured after precipitation of other lipids, LDL-cholesterol was calculated up to $10.3 \mathrm{mmol} / \mathrm{l}$ by the Friedewald formula, and for higher values the precipitation method with polycyclic anions was used. Apolipoproteins A-I and B were measured by immunoturbidimetric assay.

Statistical analysis. The results are presented as means \pm SEM. The areas under the curves (AUC) were calculated by the trapezoidal method [22]. We used the Student's $t$-test for comparing means of independent samples. The correlation between variables was calculated by linear regression. In order to eliminate the contribution of variables other than the gender of parents variance analysis with covariates was applied [23]. Two-sided $p$-values less than 0.05 were considered significant. All calculations were performed by the SPSS/PC +4.01 computer program.

\section{Results}

Blood glucose, serum insulin, C-peptide and proinsulin concentrations. In all probands the concentrations of blood glucose both in the fasting state and after glucose load were within the normal range according to the WHO criteria [20] and the mean values were not significantly different between the offspring of 

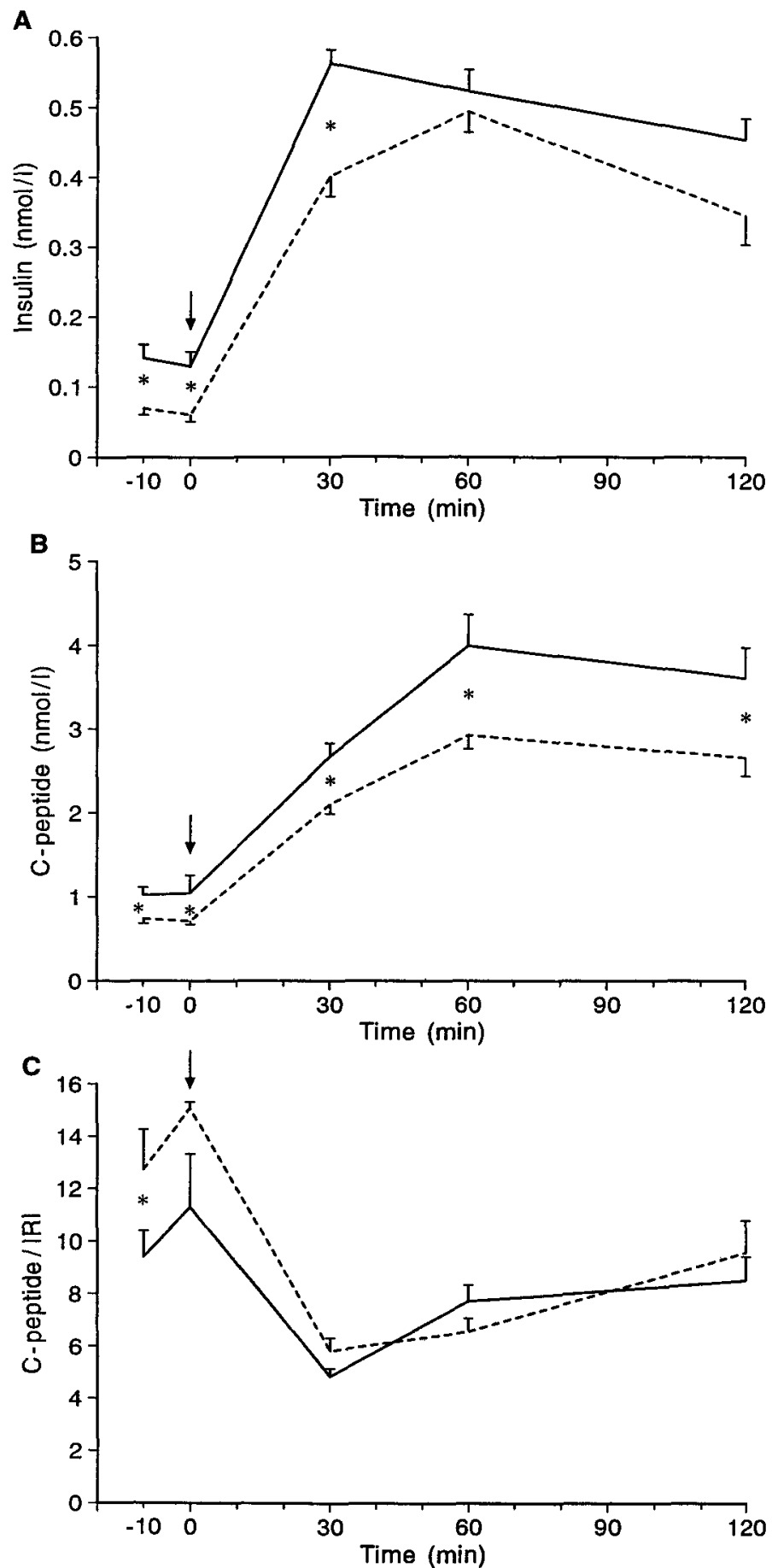

Fig. 2A-C. Serum insulin (A), C-peptide (B) and CP:IRI ratio (C) curves during OGTT (arrow) in non-diabetic adult offspring of either NIDDM mother $(-)$ or father $(--) *$ Mean group values significantly different at $p<0.05$ or less. Mean \pm SEM

NIDDM mothers and NIDDM fathers (Fig.1). In contrast, the serum insulin (IRI) concentrations were higher in offspring of diabetic mothers, and the difference between the mean values was significant at fasting, at 30 and at $120 \mathrm{~min}$ following glucose load (Fig. 2A). The difference between the mean

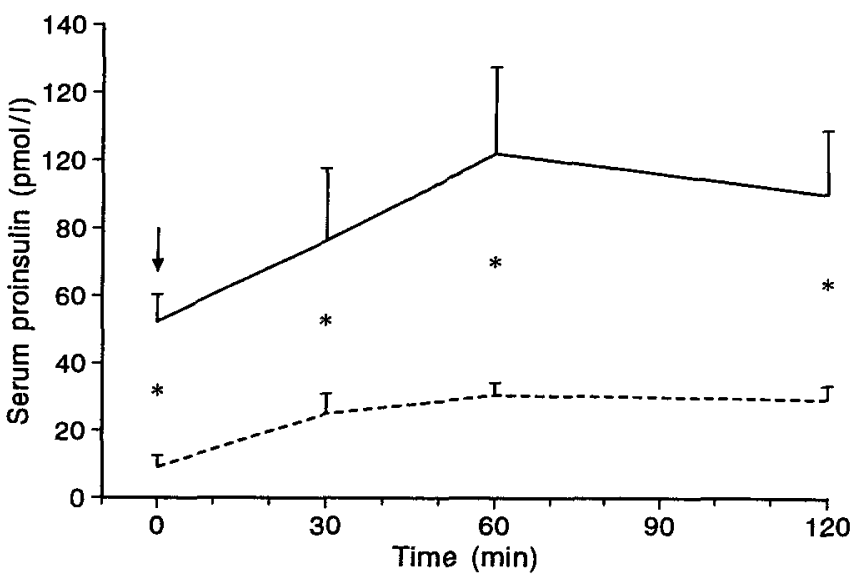

Fig.3. Serum proinsulin curves during OGTT (arrow) in nondiabetic adult offspring of either NIDDM mother $(-)$ or father $(--)$. * Mean group values significantly different at $\mathrm{p}<0.05$ or less. Mean \pm SEM

serum C-peptide values was even more pronounced, with those of the offspring of diabetic mothers being significantly higher at all times (Fig. 2B). Nevertheless, the mean serum C-peptide/IRI ratio did not differ significantly between the two groups of offspring, either in the fasting state or after glucose load (Fig. 2C). The mean serum proinsulin concentration was significantly higher in offspring of diabetic mothers than in those of diabetic fathers, at fasting and at all times following oral glucose load (Fig. 3). These differences in serum IRI, C-peptide and proinsulin concentrations between the two groups of probands were also significant after calculation of AUC (Table 3).

The age range of the probands was limited to one decade (31-40 years) which enabled us to rule out the effect of ageing on the determined parameters of pancreatic beta-cell activity. The serum IRI levels in the whole group were correlated with BMI $(r=0.378, p=0.02)$, but levels of C-peptide and proinsulin were not $(r=0.176, p=0.289$ and $r=0.209$, $p=0.208$, respectively). Accounting for BMI by covariance analysis removed the influence of the gender of the parent on serum IRI in the offspring, but not on C-peptide or proinsulin, which remained significantly higher in the offspring of diabetic mothers (Table 3).

To assess whether the effect of the gender of the diabetic parent was also dependent upon the gender of the offspring, serum levels of IRI, C-peptide and proinsulin between sons and daughters in each group, between sons of both groups, and between daughters of both groups, were compared. Both male and female offspring of NIDDM mothers had significantly higher serum concentrations of the peptides when compared with the male and female offspring of NIDDM fathers. Interestingly, in the offspring of diabetic mothers, males had considerably higher serum 
Table 3. Influence of gender of one NIDDM parent on IRI, C-peptide and proinsulin secretion expressed as serum AUC of nondiabetic offspring

\begin{tabular}{|c|c|c|c|c|c|c|c|}
\hline \multirow{2}{*}{$\begin{array}{l}\text { Serum component } \\
n\end{array}$} & \multicolumn{3}{|c|}{ Offspring of diabetic } & \multicolumn{2}{|c|}{ Effect of BMI of the offspring } & \multicolumn{2}{|c|}{ Effect of gender of the parent } \\
\hline & $\begin{array}{l}\text { Mothers } \\
20\end{array}$ & $\begin{array}{l}\text { Fathers } \\
18\end{array}$ & $p$-value & $F$ & $p$-value & $F$ & $p$-value \\
\hline $\begin{array}{l}\text { Insulin AUC } \\
\left(\mathrm{nmol} \cdot \mathrm{l}^{-1} \cdot \mathbf{h}^{-1}\right)\end{array}$ & $0.928 \pm 0.041$ & $0.757 \pm 0.056$ & 0.019 & $\begin{array}{l}6.289 \\
(d f 1.35)\end{array}$ & 0.017 & $\begin{array}{l}2.841 \\
(d f 1.35)\end{array}$ & 0.101 \\
\hline $\begin{array}{l}\text { C-peptide AUC } \\
\left(\mathrm{nmol} \cdot \mathrm{l}^{-1} \cdot \mathrm{h}^{-1}\right)\end{array}$ & $6.379 \pm 0.450$ & $4.753 \pm 0.242$ & 0.004 & $\begin{array}{l}1.918 \\
(d f 1.35)\end{array}$ & 0.175 & $\begin{array}{l}6.901 \\
(d f 1.35)\end{array}$ & 0.013 \\
\hline $\begin{array}{l}\text { Proinsulin AUC } \\
\left(\mathrm{pmol} \cdot \mathrm{l}^{-1} \cdot \mathrm{h}^{-1}\right)\end{array}$ & $172 \pm 40$ & $51 \pm 7^{\mathrm{a}}$ & 0.008 & $\begin{array}{l}1.267 \\
(d f 1.34)\end{array}$ & 0.268 & $\begin{array}{l}5.831 \\
(d f 1.34)\end{array}$ & 0.021 \\
\hline
\end{tabular}

Values are covariance analysis

${ }^{\mathrm{a}} n=17$

Table 4. Distribution of blood glucose, serum IRI, C-peptide and proinsulin after 75-g OGTT expressed as AUC in sons and daughters of one NIDDM parent

\begin{tabular}{|c|c|c|c|c|c|c|}
\hline \multirow[t]{2}{*}{ Serum component (AUC) } & \multicolumn{3}{|c|}{ Diabetic mother } & \multicolumn{3}{|c|}{ Diabetic father } \\
\hline & Sons & Daughters & $p$-value & Sons & Daughters & $p$-value \\
\hline Glycaemia $\left(\mathrm{mmol} \cdot \mathrm{l}^{-1} \cdot \mathrm{h}^{-1}\right)$ & $246 \pm 21$ & $229 \pm 15$ & 0.515 & $237 \pm 20$ & $213 \pm 12$ & 0.281 \\
\hline Insulin $\left(\mathrm{nmol} \cdot \mathbf{1}^{-1} \cdot \mathrm{h}^{-1}\right)$ & $0.897 \pm 0.072$ & $0.953 \pm 0.048$ & 0.516 & $0.672 \pm 0.048$ & $0.812 \pm 0.083$ & 0.231 \\
\hline C-peptide $\left(\right.$ nmol $\left.\cdot \mathbf{l}^{-1} \cdot \mathbf{h}^{-1}\right)$ & $7.119 \pm 0.953$ & $5.813 \pm 0.277$ & 0.212 & $4.609 \pm 0.362$ & $4.916 \pm 0.325$ & 0.547 \\
\hline Proinsulin $\left(\mathrm{pmol} \cdot \mathrm{l}^{-1} \cdot \mathrm{h}\right)$ & $288 \pm 68$ & $77 \pm 26$ & 0.015 & $46 \pm 9$ & $54 \pm 10$ & 0.591 \\
\hline C-peptide/insulin (AUC/AUC) & $7.82 \pm 0.76$ & $6.17 \pm 0.26$ & 0.067 & $7.04 \pm 0.7$ & $6.65 \pm 0.67$ & 0.704 \\
\hline
\end{tabular}

Values are mean \pm SEM

Table 5. Blood lipid profile in non-diabetic offspring of one NIDDM parent

\begin{tabular}{|c|c|c|c|}
\hline \multirow[t]{2}{*}{ Serum component } & \multicolumn{3}{|l|}{ Offspring of diabetic } \\
\hline & Mothers & Fathers & $p$-value \\
\hline$n$ & 20 & 18 & \\
\hline Triglycerides (mmol/l) & $1.53 \pm 0.24$ & $0.98 \pm 0.08$ & 0.040 \\
\hline Sons & $2.18 \pm 0.417$ & $1.22 \pm 0.197$ & 0.057 \\
\hline Daughters & $1.0 \pm 0.15\rfloor p=0.021$ & $0.94 \pm 0.11\rfloor \mathrm{NS}$ & 0.768 \\
\hline Total cholesterol (mmol/l) & $5.45 \pm 0.23$ & $5.43 \pm 0.18$ & 0.901 \\
\hline LDL cholesterol ( $\mathrm{mmol} / \mathrm{l})$ & $3.62 \pm 0.21$ & $3.70 \pm 0.23$ & 0.795 \\
\hline HDL-cholesterol (mmol/1) & $1.19 \pm 0.05$ & $1.29 \pm 0.05$ & 0.301 \\
\hline HDL/Total cholesterol ratio (\%) & $22.7 \pm 1.3$ & $24.2 \pm 1.4$ & 0.435 \\
\hline Apolipoprotein $\mathrm{A}-\mathrm{I}(\mathrm{mg} / \mathrm{dl})$ & $163 \pm 5$ & $183 \pm 8$ & 0.051 \\
\hline Apolipoprotein B (mg/dl) & $130 \pm 5$ & $121 \pm 8$ & 0.453 \\
\hline Apo-B/Apo-I ratio & $0.82 \pm 0.7$ & $0.69 \pm 0.06$ & 0.180 \\
\hline
\end{tabular}

With the exception of triglycerides the differences of other blood lipid profile parameters between sons and daughters in

proinsulin levels, and slightly (non significantly) higher serum C-peptide levels and serum C-peptide/IRI ratio, than females (Table 4). But in neither sons nor daughters of NIDDM mothers was serum proinsulin (AUC) correlated with BMI and WHR, and the positive correlation with serum triglycerides was similar in both males $(r=0.84 ; p=0.005)$ and females $(r=0.82 ; p=0.002)$ of this offspring group.

Blood lipid profile. The offspring of NIDDM mothers had significantly higher serum triglyceride levels and significantly lower serum apolipoprotein A-I levels, than offspring of NIDDM fathers (Table 5). It is again interesting to note that the male offspring of both groups and between the groups were not significant

Values are means \pm SEM

diabetic mothers had significantly higher serum triglyceride levels than females. There was no difference in other blood lipid profile parameters between male and female offspring in both groups. The serum triglycerides were significantly correlated with serum proinsulin (AUC) in both offspring groups, and when males and females were separately analysed (see above). Only in the offspring of NIDDM mothers was a significant correlation found between serum HDL-cholesterol (negative) and serum IRI (AUC) and C-peptide (AUC), and between serum apolipoprotein $B$ (positive) and serum $C$-peptide (AUC) and proinsulin (AUC); however, the separation of this group into sons and daughters showed no 
characteristic pattern of the association of these correlations with gender.

\section{Discussion}

To our knowledge, this is the first report to show that normoglycaemic, non-diabetic adult children of NIDDM mothers differ from those (in the same age range) of NIDDM fathers in having greater BMI, higher basal and stimulated (OGTT) serum levels of insulin, C-peptide and proinsulin, higher serum triglyceride and lower serum apolipoprotein A-I levels. Furthermore, we show here that the serum proinsulin and triglyceride levels are significantly higher in sons of NIDDM mothers than in daughters of NIDDM mothers. Also the serum C-peptide levels and serum C-peptide/IRI ratios are slightly (although not significantly) higher in sons than in daughters of NIDDM mothers. Of note is the difference in the serum proinsulin concentration, indicating an abnormal pancreatic beta-cell function in offspring of NIDDM mothers, particularly in the males [24]. Thus, the results support the above-quoted studies of family history of NIDDM patients demonstrating that diabetic mothers prevailed over fathers [2-5]. In addition, our results indicate that the risk of NIDDM in offspring, expressed through the impairment of betacell secretory activity, may be influenced by their gender.

The underlying mechanism of this phenomenon remains to be elucidated. Sex-linked genetic transmission and the influence of the intrauterine milieu on the fetal development are probably major factors. Similar incidence and prevalence of NIDDM in men and women prove that an $\mathrm{X}$-linked recessive trait, which is more likely to be expressed in men, is not involved. The concept of genetic imprinting is only theoretical speculation. More convincing is the hypothesis of maternally inherited mitochondrial DNA-mutation, since nearly all mitochondrial DNA is received from the ovum rather than from the sperm [25]. So far, observations of maternally inherited mitochondrial point mutations associated with glucose intolerance have been limited to sporadic cases, which are characteristic of other defects (e.g. hearing loss, neurological syndromes) and demonstrate a somewhat different course of diabetes (earlier manifestation, lower frequency of obesity, more frequent need for insulin therapy) [26-28]. Nevertheless, the contribution of mitochondrial DNA mutations to overall NIDDM incidence is an attractive hypothesis, especially as this type of diabetes presents as a multisystem disease [29].

The greater prevalence of diabetes in offspring of NIDDM mothers may also be a result of the influence of the specific intrauterine environment in fetal life. Results from studies of Pima Indians have shown that the prevalence of NIDDM is significantly higher among offspring of mothers who had had gestational diabetes than in offspring whose mothers had only had IGT during pregnancy or who developed diabetes after giving birth [30]. Aerts et al. [7] also found that experimental streptozotocin diabetes induced in rats at the beginning of the pregnancy resulted in metabolic and morphological deterioration of fetuses, with consequences (including glucose intolerance) in later life for the two following generations. Although in our study diabetes had developed after the birth of the progeny, specific changes in the intrauterine milieu during the prediabetic state could lead to the impairment of pancreatic beta-cell function and other discrete disorders. Poor fetal nutrition and, in particular, insufficient supply of amino acids, which are the major factors controlling the growth and development of pancreatic islets and other tissues seem to be of particular importance, as suggested by Freinkel [31] and expanded by others [3234]. In this study only sons of NIDDM fathers had higher birthweight, and no difference in this parameter was found between the other groups of probands, but other nutritional and non-nutritional defects, may be involved.

The finding of a significant difference in serum proinsulin between both sons and daughters of NIDDM mothers also remains unexplained. If this observation is confirmed by others, its most plausible explanation might be an increased susceptibility of male offspring of diabetic mothers to "diabetogenic" genetic and environmental factors. However, such a gender-differentiated susceptibility to NIDDM has only a marginal influence on the incidence and prevalence of this type of diabetes, as in adult life environmental diabetes risk factors have a greater influence in women than in men.

Thus far, whether the observed slight shifts in blood lipid profile in offspring (particularly in sons) of NIDDM mothers are determined by an increased secretory activity of pancreatic beta cells, or by some independent factor(s), is unclear. Nevertheless, the finding of these differences in the blood lipid profile between the offspring of NIDDM mothers and fathers in the prediabetic period may have a practical value, considering that hypertriglyceridaemia and low levels of "protective factors" (i.e. apolipoproptein A-I) along with increased serum concentrations of 32-33 split proinsulin are risk factors for cardiovascular disease [35]. However, whether NIDDM inherited from the mother rather than the father presents a greater risk for macroangiopathy can only be determined after prospective morbidity and mortality studies of children are carried out.

Acknowledgements. This study was supported in part by the grant number 4 \$402 06206 from KBN, Poland. 


\section{References}

1. Warram JH, Królewski AS, Gottlieb MS, Kahn CR (1984) Differences in risk of insulin-dependent diabetes in offspring of diabetic mothers and diabetic fathers. N Engl J Med 311: 149-152

2. Alcolado JC, Alcolado R (1991) Importance of maternal history of non-insulin dependent diabetic patients. BMJ 302: $1178-1180$

3. Mitchel BD, Valdez R, Hazuda HP, Haffner SM, Monterrosa A, Stern MP (1993) Difference in the prevalence of diabetes and impaired glucose tolerance according to maternal and paternal history of diabetes. Diabetes Care 16: $1262-1267$

4. Thomas F, Balkau B, Vauzelle-Kervroedan F, Papoz L and the Codiab-Inserm-Zeneca Study Group (1994) Maternal effect and familial aggregation in NIDDM. The Codiab Study. Diabetes 43: 63-67

5. Doria A, Warram JH (1994) How large is the contribution of a maternal effect to familial clustering of NIDDM? Diabetes 43[Suppl 1]:25A (Abstract)

6. Martin AD, Simpson JL, Ober C, Freinkel N (1985) Frequency of diabetes mellitus in mothers of probands with gestational diabetes. Possible maternal influence on the predisposition to gestational diabetes. Am J Obstet Gynecol 151: 471-475

7. Aerts L, Holemans K, Van Assche FA (1990) Maternal diabetes during pregnancy: consequences for the offspring. Diabetes Metab Rev 6: 147-167

8. Gauguier D, Nelson I, Bernard C et al. (1994) Higher maternal than paternal inheritance of diabetes in GK rats. Diabetes 43: $220-224$

9. DeFronzo RA, Bonadonna RC, Ferrannini E (1992) Pathogenesis of NIDDM: A balanced review. Diabetes Care 15: 318-368

10. Leslie RDG, Volkman HP, Poncher M, Hanning I, Orskov H, Alberti KGMM (1986) Metabolic abnormalities in children of non-insulin dependent diabetics. BMJ 293: 840-842

11. Haffner SM, Stern MP, Hazuda HP, Mitchell BD, Patterson JK (1988) Increased insulin concentrations in nondiabetic offspring of diabetic parents. N Engl J Med 319: 1297-1301

12. Warram JH, Martin BC, Królewski AS, Soeldner JS, Kahn CR (1990) Slow glucose removal rate and hyperinsulinemia precede the development of type II diabetes in the offspring of diabetic parents. Ann Intern Med 113: 909-915

13. Osei K, Cottrell DA, Orabella MM (1991) Insulin sensitivity, glucose effectiveness, and body fat disposition pattern in non-diabetic offspring of parents with NIDDM. Diabetes Care 14: $890-896$

14. Gulli G, Ferrannini E, Stern M, Haffner S, DeFronzo RA (1992) The metabolic profile of NIDDM is fully established in glucose-tolerant offspring of two Mexican-American NIDDM parents. Diabetes 41: 1575-1586

15. Jaskólska-Ladosz K, Kasperska-Czyzyk T, Juzwiak-Czapiewska D, Stepien K, Nowaczyk R (1991) Glucose tolerance and the activity of $\beta$-cells of pancreatic islets in the offspring of parents with conjugal type II diabetes (in Polish). In: Wójcikowski C (ed) Diabetes mellitus 1991. Normex, Gdansk, pp 168-176

16. Saad MF, Kahn SE, Nelson RG et al.(1990) Disproportionately elevated proinsulin in Pima Indians with non-insulin- dependent diabetes mellitus. J Clin Endocrinol Metab 70: 1247-1253

17. Beer SF, O'Rahilly S, Spivey RS, Hales CN, Turner RC (1990) Plasma proinsulin in first-degree relatives of type 2 diabetic subjects. Diabetes Research 14: 51-54

18. Krentz AJ, Clark PM, Cox L, Nattrass M (1993) Hyperproinsulinaemia in impaired glucose tolerance. Clinical Science 85: 97-100

19. Schmidli RS, Hagan C, Scott RS, Livesey J, Forbes LV (1993) Plasma proinsulin in recently diagnosed type 2 diabetes mellitus. Diabetes Res Clin Pract 20: 133-138

20. WHO Expert Committee on Diabetes Mellitus, 2nd report (1980) Technical Report Series 646. World Health Organization, Geneva

21. Bowsher RR, Wolny JD, Frank BH (1992) A rapid and sensitive radioimmunoassay for measurement of proinsulin in human serum. Diabetes 41: 1084-1090

22. Tai MM (1994) A mathematical model for the determination of total area under glucose tolerance and other metabolic curves. Diabetes Care 17: 152-154

23. Winer BJ (1962) Statistical principles in experimental design. McGraw-Hill, New York

24. Rhodes CJ, Alarcón C (1994) What $\beta$-cell defect could lead to hyperproinsulinemia in NIDDM? Some clues from recent advances made in understanding the proinsulin-processing mechanism. Diabetes 43: 511-517

25. Egger J, Wilson J (1983) Mitochondrial inheritance in a mitochondrially mediated disease. N Engl J Med 309: 142 146

26. Ballinger SW, Shoffner JM, Hedaya EV et al. (1992) Maternally transmitted diabetes and deafness associated with a $10.4 \mathrm{~kb}$ mitochondial DNA deletion. Nature Genetics 1: $11-15$

27. Reardon W, Ross RJM, Sweenay MG et al. (1992) Diabetes mellitus associated with a pathogenic point mutation in mitochondrial DNA. Lancet 340: 1376-1379

28. Kadowaki I, Kadowaki H, Mori Y et al. (1994) A subtype of diabetes mellitus associated with mutation of mitochondrial DNA. N Engl J Med 330: 962-968

29. Reaven GM (1988) Role of insulin resistance in human dis ease. Diabetes 37: 1595-1607

30. Pettit DJ, Aleck KA, Baird HR, Carraher MJ, Bennett PH, Knowler WC (1988) Congenital susceptibility to NIDDM. Role of intrauterine environment. Diabetes 37: 622-628

31. Freinkel N (1980) Of pregnancy and progeny. Diabetes 29 : 1023-1039

32. Kalkhoff RK (1991) Impact of maternal fuels and nutritional state on fetal growth. Diabetes 40[Suppl 2]:61-65

33. Hales CN, Barker DJP (1992) Type 2 (non-insulin-dependent) diabetes mellitus: the thrifty phenotype hypothesis. Diabetologia 35: 595-601

34. Breschi MC, Seghieri G, Bartolomei G et al. (1993) Relation of birthweight to maternal plasma glucose and insulin concentrations during pregnancy. Diabetologia 36: 13151321

35. Nagi DK, Hendra TJ, Ryle AJ et al. (1990) The relationship of concentration of insulin, intact proinsulin and 32-33 split proinsulin with cardiovascular risk factors in type 2 (noninsulin-dependent) diabetic subjects. Diabetologia 33: $532-537$ 